\title{
Water quality and land use/cover changes in the Phewa Watershed, Gandaki Province, Nepal
}

\author{
Kiran Bishwakarma ${ }^{1,2}$, Ramesh Raj Pant ${ }^{3,}{ }^{*}$ Khadka Bahadur Pal ${ }^{4}$, Archana Ghimire $^{2,5}$, Lal \\ B Thapa ${ }^{6}$, Prem Saud ${ }^{7}$, Susan Joshi ${ }^{8}$ and Khim Prasad Panthi ${ }^{4}$
} \author{
Academy of Sciences, Beijing 100101, China \\ ${ }^{2}$ University of Chinese Academy of Sciences, Beijing 100049, China \\ ${ }^{3}$ Central Department of Environmental Science, Tribhuvan University, Nepal \\ ${ }^{4}$ Tri-Chandra Multiple Campus, Tribhuvan University, Nepal \\ ${ }^{5}$ Research Centre for Eco-Environmental Sciences, Chinese Academy of Sciences, Beijing, China \\ ${ }^{6}$ Central Department of Botany, Tribhuvan University, Nepal \\ ${ }^{7}$ Kailali Multiple Campus, Tribhuvan University, Nepal \\ ${ }^{8}$ Central Department of Chemistry, Tribhuvan University, Nepal
}

${ }^{1}$ Key Laboratory of Tibetan Environment Changes and Land Surface Processes, Institute of Tibetan Plateau Research, Chinese

\begin{abstract}
Knowledge and understanding of land use and water quality nexus is an important precursor for assessing the human-water interactions and sustainable freshwater management. In this study, the land use/cover change (LUCC) and water quality assessment with respect to drinking and irrigational purposes were carried out in Phewa Lake, Nepal. A total of 20 water samples were collected during the winter and summer seasons in 2017 and were analysed for major hydrochemical variables. The water quality index of Phewa Lake was found to be 5.15 and 2.57 during the winter and summer, respectively, indicating the suitability of water for drinking purposes. The results revealed that the electrical conductivity, sodium percentage, and sodium adsorption ratio were found to be $38.80 \mu \mathrm{S} / \mathrm{cm}, 16.99$, and 0.10 , respectively in the summer and 85.06 $\mu S / \mathrm{cm}, 14.68$, and 0.15 , respectively in the winter. Similarly, permeability index, Kelly's ratio, magnesium hazard, cation ratio of soil structural stability, and Wilcox diagram exhibited that the water was suitable for irrigation in both seasons with relatively better quality in the summer. The dynamic pattern of LUCC in the Phewa watershed exhibited an increase in the spatial extent of forest, shrub-land, grassland, and built-up area, whereas decreasing trend of agricultural land, barren land, and water bodies. Irrespective of the seasonality, the LUCC-water quality nexus showed elevated concentrations in the proximity of the urban settlements. The present study could be helpful for the restoration of water quality by sustainable land-use practices in the Himalayan region.
\end{abstract}

Keywords: Drinking water quality, Irrigational quality indices, Land use pattern, Phewa Lake

\section{Introduction}

The freshwater chemistry is controlled by both natural and anthropic factors. The natural factors include precipitation, rock weathering, and evapo-crystallization whereas, the anthropic factors are agricultural runoff, domestic and municipal effluents (Paudyal et al., 2016a; 2016b; Pant et al., 2019a; Pal et al., 2019). Previous studies demonstrated that the lake water quality has been deteriorated noticeably in many parts of the world during the last few decades owing to the unmanaged land use practices ( $\mathrm{Li}$ et al., 2009; Davids et al., 2018). These studies have revealed a strong relationship between water quality deterioration and expansion of urban settlement and industrial areas. Additionally, anthropic activities including land use/cover changes (LUCC) have dramatically reduced the natural restoring capacity of the aquatic ecosystem. The LUCC analysis of the aquatic environment in basin-scale was a better indicator of water quality, especially in the urban-based aquatic system (Hunsaker \& Levine, 1995). Therefore, the current research pattern has been paying more attention to the appraisal of LUCC and water quality nexus, especially contamination of municipal effluents and agricultural runoff in developing countries like Nepal. The aquatic buffer areas including undisturbed vegetation, natural land topography, and swampy areas, have a great role in neutralizing the pollutants by detoxification of its natural processes (Singh et al., 2016). Likewise, the wetland ecosystems have a vital role in improving the water quality (Pant \& Adhikari, 2015; Sharma et al., 2015; Pant et al., 2019b).

Phewa Lake is one of the major water sources in the Pokhara Metropolitan City, Nepal, where more than 0.5 million inhabitants are using water resources from the lake basin (CBS, 2011). The water is widely used for domestic, irrigation, industrial, recreational, and commercial purposes (Gurung et al., 2005). The lake is formed by a natural process and regulated by an artificial dam. Being a Ramsar site (No. 2257), Phewa Lake is a wetland of international importance. As the Phewa Lake falls under the heavy monsoon regime in Nepal, it receives an enormous water influx from June to September, and the

"Corresponding author: rpant@cdes.edu.np 
rest of the months, the lake receives water from the tributaries and groundwater seepage (Watson et al., 2019). The lake is fed by two perennial streams: namely the Harpan Khola and Andheri Khola, as well as several other seasonal streams, and the water of the lake exits through an outlet at the Dam site area throughout the year. In order to keep the Phewa Lake from being affected by exogenous pollution, no special controlling devices have been set up at the inlets and other locations of the lake, so there is still a huge amount of sewage continuously discharging into the lake from the surrounding settlements, hotels, urban areas, and farmlands. The Phewa Lake also has immense importance in terms of socio-economic values and livelihood supports. Besides, the famous temple (Tal Barahi) situated in the middle of the lake representing high cultural and religious values. Nevertheless, the massive flow of pilgrims is responsible for contamination in the lake water.

There are several studies conducted in Phewa and associated lakes of the Pokhara valley (Gurung et al., 2005; Khadka \& Ramanathan, 2013; Heyojoo \& Takhachhe, 2014; Pant \& Adhikari, 2015; Sharma et al., 2015; Rupakheti et al., 2017). Sharma et al. (2015) has confirmed the presence of mercury contamination due to moderate chemical weathering of surrounding rocks and rapid urbanization in the surrounding areas of the lake. However, most of the previous studies are primarily focused on general hydrochemistry, trace elements, aquatic biodiversity, etc., but none of them were focused on water quality assessment particularly with respect to LUCC. Thus, the objective of this study is to assess the drinking and irrigational water suitability of Phewa Lake, Gandaki Province, Nepal, concerning the LUCC.

\section{Materials and Methods}

Study area

The Phewa Lake is one of the most important lentic ecological features, located in the mid-hills $\left(28^{\circ} 12^{\prime} \mathrm{N}\right.$, $\left.82^{\circ} 56^{\prime} \mathrm{E}\right)$ at an altitude of $782 \mathrm{~m}$ asl in the Gandaki Province, Nepal (Fig. 1). It has a surface area of $4.35 \mathrm{~km}^{2}$ and a maximum depth of $22.5 \mathrm{~m}$ (Sharma et al., 2015). The region has a humid climatic condition with a maximum temperature peak at $25.5^{\circ} \mathrm{C}$ in July-August and falls to a minimum at $13.2^{\circ} \mathrm{C}$ in January (Pant \& Adhikari, 2015; Pant et al., 2019b). It has a watershed area of $\sim 150 \mathrm{~km}^{2}$. By land use pattern, the lake features have sparse rural settlements on the southern side, agricultural land with dense urban areas on the northeast side, and a river channel zone on the western side of the lakeshore (Fort et al., 2018). The rock distribution in the watershed is predominated by sedimentary and metamorphic rocks, whereas igneous rock has a limited distribution. The watershed consists of geological features of lesser Himalayan rocks, i.e., slate, dolomite, limestone, siltstone, quartzite, schist, muscovite, and carbonaceous shale (Dhital, 2015). The soils in the basin are mostly formed from the lacustrine deposit, including parent rock weathering with medium to high organic matter contents (Khadka \& Ramanathan, 2013).

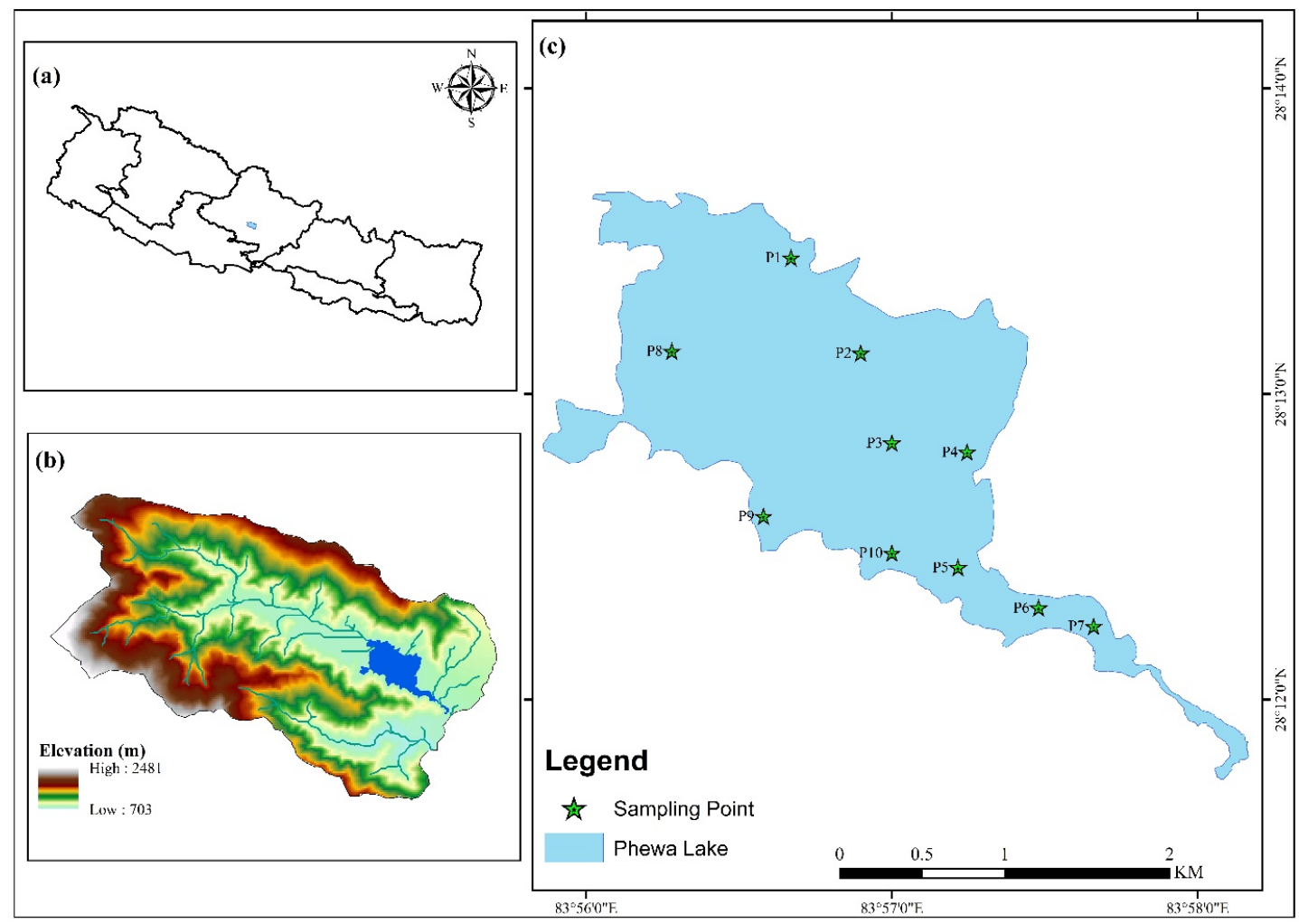

Figure 1 Location map of the study area (a): Phewa Watershed in Nepal, (b): Elevation map of Phewa Watershed, and (c): Sampling locations in the Phewa Lake, Gandaki Province, Nepal. 


\section{Sample collection and analysis}

The water samples were collected from 10 different locations in two seasons, i.e., winter (January 2017) and summer (July 2017) (Fig. 1c). The sampling locations are selected in such a way that the major sources of pollutants, inlet, center, outlet, and major land use pattern were considered (Fig. 1). Due to time and resource constraints, only ten sampling locations were studied in each season. A total of 20 water samples were collected (per location one sample in two seasons) in polyethylene sampling bottles of 1 liter (L) size, using disposable plastic gloves. The samples from each site were collected at $20 \mathrm{~cm}$ below the surface and stored in polyethylene plastic bottles at $4{ }^{\circ} \mathrm{C}$ before laboratory analyses. In order to have consistent data, sampling was performed at the same sites, and a handheld GPS was used to determine the locations of the sampling sites. The surface water quality was assessed by analysis of seven hydrochemical parameters, including electrical conductivity (EC) and total dissolved solids (TDS), which were directly determined in-situ using a multi-parameter water quality monitoring instrument (HI-98129, HANNA, Romania). $\mathrm{HCO}_{3}^{-}$was analysed by titration method (APHA, 2005). The major cations such as $\mathrm{Ca}^{2+}, \mathrm{Mg}^{2+}, \mathrm{K}^{+}$, and $\mathrm{Na}^{+}$ were analysed at the Institute of Tibetan Plateau Research, Chinese Academy of Sciences, Beijing, China using ICP-MS. The LUCC of Nepal (the year 2000, the year 2010) published by ICIMOD (30 $\mathrm{m}$ resolution) were used to analyse the land use changing pattern of the Phewa Watershed in the ArcGIS environment.

\section{Water quality assessment}

The drinking water quality of the lake water was assessed by Water Quality Index (WQI) based on seven hydrochemical variables including EC, TDS, major cations $\left(\mathrm{Ca}^{2+}, \mathrm{Mg}^{2+}\right.$, $\mathrm{Na}^{+}, \mathrm{K}^{+}$), and $\mathrm{HCO}_{3}{ }^{-}$using standard permissible limit recommended by World Health Organization (WHO) (Sahu $\&$ Sikdar, 2008). The weight assigned for the drinking water quality in the range of 1-5 to each of the chemical variables according to their relative importance for drinking purposes as suggested by different standards and previous studies (Sahu \& Sikdar, 2008; Wu et al., 2009; Tripathee et al., 2016). Similarly, the assessment suitability of the lake water for irrigation was performed by using the standard parameters such as electric conductivity (EC), sodium percentage $(\mathrm{Na} \%)$, sodium adsorption ratio (SAR), magnesium hazard $(\mathrm{MH})$, Kelly's ratio (KR), permeability index (PI), cation ratio of soil structural stability (CROSS), and Wilcox diagram (Alavi et al., 2016; Kumari, 2017).

\section{Results and Discussion}

\section{Drinking water quality}

The drinking suitability of Phewa Lake water during the winter and summer seasons had been evaluated and presented in Table 1. The WQI of the lake water during winter and summer was 5.74 and 3.05, respectively, with an average of 4.39 indicating the 'excellent' category for the drinking purpose. The seasonal variation of WQI showed comparatively better quality during the summer season. The less contamination in lake water during the summer season might be due to the rise in water level, which causes the chemical dilution (Pant et al., 2019b). During both seasons,
P9 had the highest WQI (7.12 and 5.37 during the winter and summer seasons, respectively) indicating the anthropic interferences, including hotels and polluted areas. Meanwhile, the WQI was observed lowest in P5 (4.62) and P2 (2.07) during the winter and summer seasons, respectively. While comparing the water quality of Phewa Lake with other freshwater environments of the Himalayas, the results of this study indicated that the lake water can be used for drinking purposes (Tripathee et al., 2016). However, some of the previous studies conducted in the same lake suggested that the markedly high values of WQI, which could be due to the additional evaluation of potentially toxic trace elements such as As and $\mathrm{Hg}$ (Sharma et al., 2015; Rupakheti et al., 2017). The overall WQI of all the sampling points exhibited suitable for drinking purposes to the specific chemical parameters that were chosen in this study in both the summer and winter seasons (Table A2).

\section{Irrigation water quality}

The irrigation suitability of the Phewa Lake water during the winter and summer seasons had been evaluated using different methods, and the computed value has been presented in Table 1. The water used for irrigation with high $\mathrm{Na}^{+}$and low $\mathrm{Ca}^{2+}$ contents will adversely affect the soil structure due to the dispersion of the clay particles (Fipps, 1995). The higher concentration of $\mathrm{Na}^{+}$in the irrigation water not only affects the ion exchange in the soil, such as $\mathrm{Ca}^{2+}$ and $\mathrm{Mg}^{2+}$ but also reduces its permeability, causing calcium deficiency, deflocculation, and impairment of the tilth (Singh et al., 2012). The chemical and physical characteristics of lake water used for irrigation purposes are the basic consideration for the irrigation water quality evaluation.

The average value of EC during winter and summer was $86.71 \mu \mathrm{S} / \mathrm{cm}$ and $36.52 \mu \mathrm{S} / \mathrm{cm}$, respectively, with an average of $61.62 \mu \mathrm{S} / \mathrm{cm}$ indicating excellent for irrigational uses. Na $\%$, also known as sodium hazard, is an indication of the soluble sodium content of the irrigation water (Doneen, 1954). The $\mathrm{Na} \%$ in the Phewa Lake during winter and summer was 14.62 and 18.21 , respectively. The SAR values of Phewa Lake during both seasons (winter: 0.15 and summer: 0.10) were less than 1. The Magnesium Hazard $(\mathrm{MH})$ in irrigation water less than 50 is acceptable for irrigational purposes (Raghunath, 1987). Based on $\mathrm{MH}$ values, the lake water was suitable for irrigation in both seasons. Moreover, KR values of both seasons were less than 1 belonging to the safe category. Similarly, CROSS values of all the samples during the winter and summer seasons were also calculated less than 1 . All the measured parameters were within the recommended guidelines exhibiting the Phewa Lake water as safe for irrigational uses. The Wilcox diagram illustrated that all the sampling points plotted into the C1S1 section (low salinity and conductivity), consistently indicating the suitability of lake water for irrigational uses (Fig. 2). During the winter season, the EC, SAR, KR, PI, and CROSS values reflected the relatively poor condition in the P9. The $\mathrm{Na} \%$ and $\mathrm{MH}$ value were observed the highest in P3. The poor irrigational water quality index in P9 during the winter season was mainly due to the anthropic pressure from the nearby settlements. 
Table 1 Results of drinking and irrigation water quality analysis of the Phewa Lake, Gandaki Province, Nepal

\begin{tabular}{llll}
\multirow{2}{*}{ Parameter } & Winter & Summer & Average \\
\cline { 2 - 4 } & Value (Category) & Value (Category) & Value (Category) \\
\hline WQI & 5.15 (Excellent) & 2.57 (Excellent) & 3.86 (Excellent) \\
EC $(\boldsymbol{\mu S} / \mathbf{c m})$ & 85.06 (Excellent) & 38.80 (Excellent) & 61.93 (Excellent) \\
$\mathbf{N a \%}$ & 14.68 (Excellent) & 16.99 (Excellent) & 15.83 (Excellent) \\
$\mathbf{S A R}$ & 0.15 (Excellent) & 0.10 (Excellent) & 0.12 (Excellent) \\
$\mathbf{M H}$ & 18.22 (Suitable) & 21.51 (Suitable) & 19.86 (Suitable) \\
$\mathbf{K R}$ & 0.12 (Safe) & 0.12 (Safe) & 0.12 (Safe) \\
$\mathbf{P I}$ & 99.87 (Class I) & 127.45 (Class I) & 113.66 (Class I) \\
$\mathbf{C R O S S}$ & 0.19 (Excellent) & 0.15 (Excellent) & 0.17 (Excellent) \\
\hline
\end{tabular}

Likewise, the $\mathrm{Na} \%, \mathrm{MH}$, and $\mathrm{KR}$ were found relatively higher in P5, whereas the SAR and CROSS were found to be higher in P3. Interestingly, $\mathrm{Na} \%, \mathrm{SAR}, \mathrm{KR}$, and CROSS were found to be relatively better quality in $\mathrm{P} 9$ during the summer season. The intense changes in irrigational water quality during the summer season in the $\mathrm{P} 9$ might be due to the less human disturbances and high surface flow by monsoon driven climatic pattern.

\section{LUCC and water quality nexus}

The land use/cover change (LUCC) of the Phewa Lake watershed is presented in Fig. 3 and Table 2. The seven major land-use types were observed mainly forest, agricultural land, water bodies, grassland, barren land, shrubland, and built-up area. The pattern of LUCC of the Phewa lake watershed demonstrated an increase in the spatial extent of forest, shrub-land, grassland, and built-up area, whereas decreasing the spatial extent of agricultural land, barren land, and water bodies (Table 2). The expansion of forest and a notable decline in agricultural land in 2010 indicated the effectiveness of community-based forest management and increased dependency on liquefied petroleum gas rather than on wood.

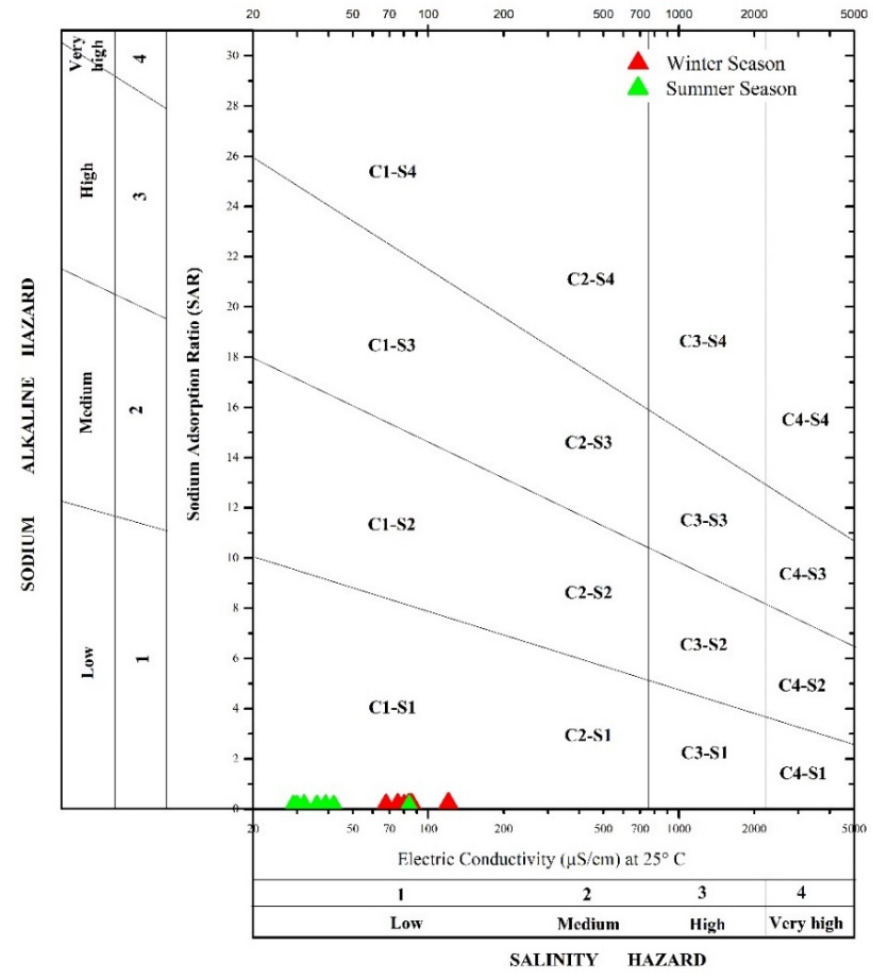

Figure 2 Wilcox diagram illustrating the irrigational water quality based on SAR and EC of the Phewa Lake, Gandaki Province, Nepal. 


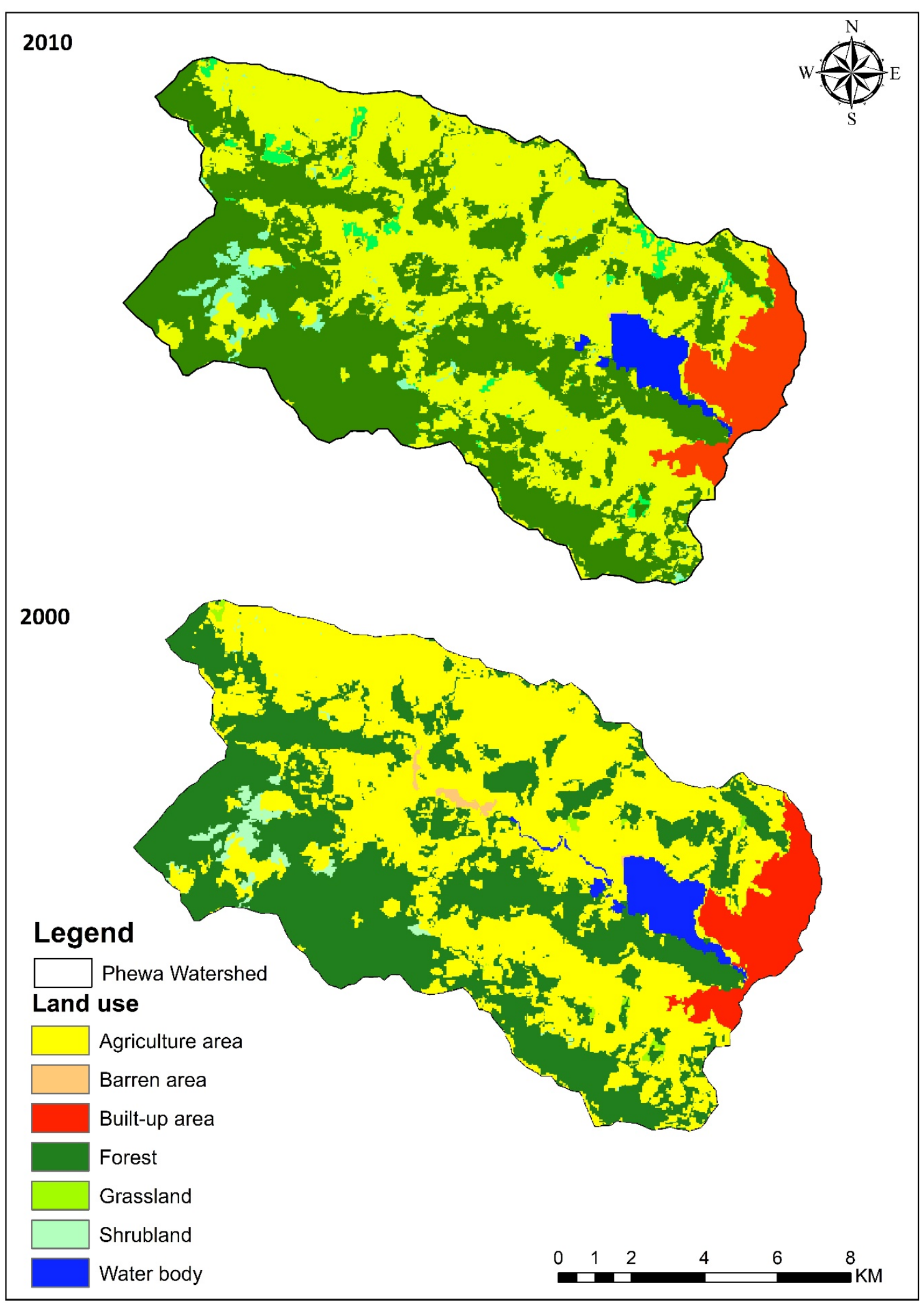

Figure 3 Land use/cover change (LUCC) map for the Phewa Watershed in 2010 and 2000 (Source: Uddin et al., 2015) 
Table 2 Land use/cover changes in the Phewa Watershed in the year 2000 and 2010

\begin{tabular}{|c|c|c|c|}
\hline Land use & Area $\left(\mathrm{km}^{2}\right)$ in 2000 & Area $\left(\mathrm{km}^{2}\right)$ in 2010 & Change in the area $(\%)$ \\
\hline Forest land & 61.98 & 66.03 & 2.64 \\
\hline Shrub-land & 2.10 & 2.57 & 0.31 \\
\hline Grass land & 0.56 & 2.47 & 1.24 \\
\hline Agriculture land & 75.49 & 69.85 & -3.66 \\
\hline Barren land & 0.55 & 0.04 & -0.33 \\
\hline Water bodies & 4.23 & 3.65 & -0.38 \\
\hline Built-up area & 8.93 & 9.21 & 0.18 \\
\hline
\end{tabular}

The increase in the built-up area could be attributed to population growth and urbanization. The encroaching pattern of Phewa Lake was mainly due to anthropic activities surrounding the lake area. The study by Heyojoo \& Takhachhe (2014) assessed the lake area shrinkage through a geospatial approach and concluded that the lake area is shrinking annually with the rate of $0.46 \%$ ( 2 ha per year), which also supported the land encroachment in the vicinity.

In the Phewa watershed, the water quality is relatively better in the summer season than that of the winter season. However, the LUCC has a paramount role in both the study seasons for determining the overall water quality of the lake basin. For instance, the catchment/land use in P1 and P5 sampling sites were characterized by the dense forest, i.e., the Raniban area, and had low concentrations of total dissolved solids during both winter and summer seasons. On the other hand, some sampling points, for instance, P9 is located in the proximity of settlements with commercial areas including hotels, were characterized by the elevated concentration of TDS (Table A1). This indicated that LUCC has a pivotal role in determining the water quality of the aquatic environment irrespective of sampling periods. The forest coverage and vegetative region adjacent to the aquatic environment can greatly mitigate nutrients and sediment contents, which have a crucial role in the controlling mechanism of hydrochemistry (Li et al., 2009). Although the major cations display marked spatiotemporal differences, the sampling sites nearby the dense forest area had more or less similar concentrations.

\section{Conclusion}

This study analyses the water quality of the Phewa Lake in association with land use/cover change (LUCC) and revealed that relatively better water quality was found in the summer as compared to the winter season. The EC, $\mathrm{Na} \%$, and sodium adsorption ratio results implied that the water quality of the Phewa Lake lies in the excellent category in both sampling periods with relatively better quality in the summer season. At the same time, magnesium hazard and Kelly's ratio indicated that the water lies in the category of suitable and safe, respectively, in both the seasons. Additionally, the WQI of Phewa Lake indicates the suitability of water for drinking purposes in both seasons, respectively, indicating the suitability of water for drinking purposes in both seasons based on measured chemical parameters in this study. While comparing the variables with the WHO guidelines, the water quality parameters are found within the standard limits for drinking purposes.

The analysis demonstrates that the forest area, shrub-land, grassland, and built-up area in the watershed were increased, whereas agricultural land, surface area of the lake, and barren land were decreased. Moreover, the sampling sites located in the proximity of built-up area, urban area, and municipal drainage sites are characterized by the elevated concentration of hydrochemical variables, and thus relatively poor drinking and irrigational water quality were observed in the respective sites. Interestingly, the increasing trend of forest coverage could be a good indicator of restoring the watershed area during the last few decades and is a positive symbol for environmental perspectives. The results of this study could be useful for the academia, policymakers, and other concerned stakeholders for the sustainable water quality management and livelihoods improvements of the local people. The authors recommended that further indepth study should be conducted incorporating microbial parameters.

\section{Acknowledgements}

The authors are thankful to Prof. Zhang Fan for her guidance during the preparation of manuscript. The authors are grateful to the Central Department of Environmental Science, Tribhuvan University for the necessary support in this research work.

\section{References}

Alavi, N., Zaree, E., Hassani, M., Babaei, A.A., Goudarzi, G., Yari, A.R., \& Mohammadi, M.J. (2016). Water quality assessment and zoning analysis of Dez eastern aquifer by Schuler and Wilcox diagrams and GIS. Desalination and Water Treatment, 57(50), 23686-23697. doi 10.1080/19443994.2015.1137786.

APHA. (2005). Standard Methods for the Examination of Water and Wastewater. American Public Health Association, Washington DC. 1-1220.

CBS. (2011). National Population and Housing Census 2011 (National Report). Central Bureau of Statistics, https://cbs.gov.np/national-population-and-housingcensus-2011national-report/

Davids, J.C., Rutten, M.M., Shah, R.D.T., Shah, D.N., Devkota, N., Izeboud, P., Pandey, A., \& van de Giesen, N. (2018). Quantifying the connections-linkages between land-use and water in the Kathmandu valley, Nepal. 
Environmental Monitoring and Assessment, 190(5), 304. do 10.1007/s10661-018-6687-2.

Dhital, M.R. (2015). Geology of the Nepal Himalaya: regional perspective of the classic collided orogen. Springer. doi 10.3126/ije.v3i2.10502.

Doneen, L.D. (1954). Salination of soil by salts in the irrigation water. American Geophysical Union, 35, 3-7.

Fipps, G. (1995). Standards and salinity management and salinity management water analysis. Agrilife Extension, 4(3), $1-17$.

Fort, M., Adhikari, B.R., \& Rimal, B. (2018). Pokhara (central Nepal): A dramatic yet geomorphologically active environment versus a dynamic, rapidly developing city. In Thornbush, M.J., \& Allen, C.D. (Eds.) Urban Geomorphology: Landforms and Processes in Cities. Elsevier Inc. doi 10.1016/B978-0-12-811951-8.00012-6.

Gurung, T.B., Wagle, S.K., Bista, J.D., Joshi, P.L., Batajoo, R., Adhikari, P., \& Rai, A.K. (2005). Participatory fisheries management for livelihood improvement of fishers in Phewa Lake, Pokhara, Nepal. Himalayan Journal of Sciences, 3(5), 47-52. doi 10.3126/hjs.v3i5.461.

Heyojoo, B.P., \& Takhachhe, P. (2014). An assessment of lake area shrinkage through geospatial approach: Case study of Phewa Lake of Kaski district, Nepal. International Journal of Multidisciplinary and Current Research, 2, 725-728.

Hunsaker, C.T., \& Levine, D.A. (1995). Hierarchical approaches to the study of water quality in rivers. BioScience, 45(3), 193-203. doi 10.2307/1312558.

Khadka, U.R., \& Ramanathan, A.L. (2013). Major ion composition and seasonal variation in the Lesser Himalayan lake: Case of Begnas Lake of the Pokhara valley, Nepal. Arabian Journal of Geosciences, 6(11), 41914206. doi 10.1007/s12517-012-0677-4.

Kumari, P. (2017). Irrigation water quality based on hydro chemical analysis of Ganga-Sone Divide Region of Bihar. Asian Journal of Water, Environment and Pollution, 14(3), 7583. doi 10.3233/AJW-170028.

Li, S., Gu, S., Tan, X., \& Zhang, Q. (2009). Water quality in the upper Han River basin, China: The impacts of land use/land cover in riparian buffer zone. Journal of Hazardous Materials, 165(1-3), 317-324. doi 10.1016/j.jhazmat.2008.09.123.

Pal, K.B., Pant, R.R., Rimal, B., \& Mishra, A.D. (2019). Comparative assessment of water quality in the Bagmati River basin, Nepal. Zoo-Journal, 5, 68-78.

Pant, R.R., \& Adhikari., N.L. (2015). Water quality assessment of Phewa Lake, Pokhara Nepal. Cognition-A Transdisciplinary Research Journal, 1, 130-140.

Pant, R.R., Dhakal, T.M., Thapa, L.B., Baral, U., Dangol, A., Chalaune, T.B., \& Pal, K.B. (2019a). Water quality assessment of the Betkot Lake, Sudurpaschim Province, Nepal. North American Academic Research, 2 (12), 36-62. doi 10.5281/zenodo.3566682.

Pant, R.R., Pal, K.B., Adhikari, N.L., Adhikari, S., \& Mishra, A.D., (2019b). Water quality assessment of Begnas and Rupa Lakes, Lesser Himalaya Pokhara, Nepal. Journal of the Institute of Engineering, 15(2), 113-122. doi 10.3126/jie.v15i2.27655.
Paudyal, R., Kang, S., Sharma, C.M., Tripathee, L., Huang, J., Rupakheti, D., \& Sillanpää, M. (2016a). Major ions and trace elements of two selected rivers near Everest region, southern Himalayas, Nepal. Environmental Earth Sciences, 75(1), 1-11. doi 10.1007/s12665-015-4811-y.

Paudyal, R., Kang, S., Sharma, C.M., Tripathee, L., \& Sillanpaä, M. (2016b). Variations of the physicochemical parameters and metal levels and their risk assessment in urbanized Bagmati River, Kathmandu, Nepal. Journal of Chemistry, 6025905. doi 10.1155/2016/6025905.

Raghunath, H.M. (1987). Ground Water. New Age International, New Delhi, India.

Rupakheti, D., Tripathee, L., Kang, S., Sharma, C.M., Paudyal, R., \& Sillanpää, M. (2017). Assessment of water quality and health risks for toxic trace elements in urban Phewa and remote Gosainkunda lakes, Nepal. Human and Ecological Risk Assessment, 23(5), 959-973. doi 10.1080/10807039.2017.1292117.

Sahu, P., \& Sikdar, P.K. (2008). Hydrochemical framework of the aquifer in and around East Kolkata Wetlands, West Bengal, India. Environmental Geology, 55(4), 823-835. doi 10.1007/s00254-007-1034-x.

Sharma, C.M., Kang, S., Sillanpää, M., Li, Q., Zhang, Q., Huang, J., Tripathee, L., Sharma, S., \& Paudyal, R. (2015). Mercury and selected trace elements from a remote (Gosainkunda) and an urban (Phewa) lake waters of Nepal. Water, Air, and Soil Pollution, 226(2). doi 10.1007/s11270-014-2276-3.

Singh, A.K., Mahato, M.K., Neogi, B., Tewary, B.K., \& Sinha, A. (2012). Environmental geochemistry and quality assessment of mine water of Jharia coalfield, India. Environmental Earth Sciences, 65(1), 49-65. doi 10.1007/s12665-011-1064-2.

Singh, V.B., Ramanathan, A.L., \& Mandal, A. (2016). Hydrogeochemistry of high-altitude lake: a case study of the Chandra Tal, Western Himalaya, India. Arabian Journal of Geosciences, 9(4), 1-9. doi 10.1007/s12517-016-2358-1.

Tripathee, L., Kang, S., Sharma, C.M., Rupakheti, D., Paudyal, R., Huang, J., \& Sillanpää, M. (2016). Preliminary health risk assessment of potentially toxic metals in surface water of the Himalayan Rivers, Nepal. Bulletin of Environmental Contamination and Toxicology, 97(6), 855-862. doi 10.1007/s00128-016-1945-x.

Uddin, K., Shrestha, H.L., Murthy, M.S.R., Bajracharya, B., Shrestha, B., Gilani, H., Pradhan, S., \& Dangol, B. (2015). Development of 2010 national land cover database for the Nepal. Journal of Environmental Management, 148, 82-90. doi 10.1016/j.jenvman.2014.07.047.

Watson, C.S., Kargel, J.S., Regmi, D., Rupper, S., Maurer, J. M., \& Karki, A. (2019). Shrinkage of Nepal's second largest lake (Phewa Tal) due to watershed degradation and increased sediment influx. Remote Sensing, 11(4), 1-17. doi $10.3390 /$ rs11040444.

Wu, B., Zhao, D.Y., Jia, H.Y., Zhang, Y., Zhang, X.X., \& Cheng, S.P. (2009). Preliminary risk assessment of trace metal pollution in surface water from Yangtze River in Nanjing section, China. Bulletin of Environmental Contamination and Toxicology, 82(4), 405-409. doi 10.1007/s00128-008-9497-3. 


\section{Annex}

Table A1 Hydrochemical variables of the Phewa Lake Basin during winter and monsoon season (all are express in mg/L except EC $(\mu \mathrm{S} / \mathrm{cm})$

\begin{tabular}{|c|c|c|c|c|c|c|c|c|}
\hline Seasons & Sampling ID & $\mathrm{EC}$ & TDS & $\mathrm{Ca}^{2+}$ & $\mathrm{Mg}^{2+}$ & $\mathrm{K}^{+}$ & $\mathrm{Na}^{+}$ & $\mathrm{HCO}_{3}-$ \\
\hline \multirow{11}{*}{$\begin{array}{l}\text { Winter } \\
\text { Season }\end{array}$} & P1 & 86.00 & 61.80 & 13.36 & 1.66 & 1.36 & 2.38 & 35.47 \\
\hline & P2 & 83.70 & 64.40 & 11.66 & 1.58 & 1.23 & 1.97 & 31.32 \\
\hline & P3 & 75.60 & 53.30 & 10.97 & 1.88 & 1.59 & 2.23 & 32.65 \\
\hline & P4 & 80.30 & 56.80 & 11.92 & 1.60 & 1.18 & 1.90 & 32.38 \\
\hline & P5 & 67.90 & 47.90 & 11.40 & 1.48 & 1.25 & 1.90 & 30.50 \\
\hline & P6 & 83.50 & 59.20 & 11.82 & 1.60 & 1.28 & 2.09 & 32.29 \\
\hline & P7 & 83.50 & 59.20 & 11.42 & 1.50 & 1.24 & 1.96 & 30.58 \\
\hline & P8 & 84.70 & 60.30 & 12.08 & 1.55 & 1.22 & 1.88 & 32.48 \\
\hline & P9 & 120.40 & 89.00 & 15.99 & 1.98 & 1.67 & 3.34 & 43.60 \\
\hline & P10 & 85.00 & 54.00 & 10.96 & 1.53 & 1.25 & 2.01 & 30.32 \\
\hline & Average & 85.06 & 60.59 & 12.16 & 1.64 & 1.33 & 2.17 & 33.16 \\
\hline \multirow{12}{*}{$\begin{array}{l}\text { Monsoon } \\
\text { Season }\end{array}$} & PL3 & 30.00 & 15.00 & 4.67 & 0.80 & 1.01 & 0.88 & 10.97 \\
\hline & PL5 & 29.00 & 15.00 & 4.62 & 0.80 & 0.98 & 0.87 & 10.87 \\
\hline & PL7 & 32.00 & 16.00 & 4.90 & 0.94 & 1.04 & 1.09 & 11.45 \\
\hline & PL9 & 32.00 & 16.00 & 4.99 & 0.83 & 0.99 & 0.92 & 11.64 \\
\hline & PL11 & 32.00 & 15.00 & 4.39 & 0.91 & 1.17 & 0.97 & 10.36 \\
\hline & PL12 & 31.00 & 15.00 & 4.76 & 0.82 & 0.99 & 0.87 & 11.16 \\
\hline & PL13 & 39.00 & 20.00 & 6.29 & 0.89 & 1.10 & 1.09 & 14.43 \\
\hline & PL15 & 32.00 & 16.00 & 4.71 & 0.84 & 1.01 & 0.92 & 11.06 \\
\hline & PL17 & 36.00 & 17.00 & 4.77 & 0.81 & 0.96 & 0.91 & 11.18 \\
\hline & PL21 & 84.00 & 42.00 & 16.72 & 1.82 & 1.44 & 1.53 & 36.68 \\
\hline & PL25 & 42.00 & 22.00 & 5.62 & 0.91 & 1.38 & 1.00 & 12.99 \\
\hline & Average & 38.09 & 19.00 & 6.04 & 0.94 & 1.10 & 1.00 & 13.89 \\
\hline
\end{tabular}


Table A2 Irrigational water quality analysis of Phewa Lake water during winter and monsoon season

\begin{tabular}{|c|c|c|c|c|c|c|c|c|c|c|c|c|c|c|c|c|c|}
\hline Seasons & $\begin{array}{l}\text { Sampling } \\
\text { ID }\end{array}$ & WQI & Category & EC & Category & $\mathrm{Na} \%$ & Category & SAR & Category & MH & Category & KR & Category & PI & Category & CROSS & Category \\
\hline \multirow{11}{*}{ Winter season } & P1 & 5.51 & Excellent & 86.00 & Excellent & 14.69 & Excellent & 0.16 & Excellent & 17.01 & Suitable & 0.13 & Safe & 95.52 & Class I & 0.20 & Excellent \\
\hline & P2 & 5.19 & Excellent & 83.70 & Excellent & 14.13 & Excellent & 0.14 & Excellent & 18.27 & Suitable & 0.12 & Safe & 100.60 & Class I & 0.18 & Excellent \\
\hline & P3 & 5.12 & Excellent & 75.60 & Excellent & 16.40 & Excellent & 0.16 & Excellent & 22.04 & Suitable & 0.14 & Safe & 103.71 & Class I & 0.21 & Excellent \\
\hline & P4 & 4.98 & Excellent & 80.30 & Excellent & 13.45 & Excellent & 0.14 & Excellent & 18.13 & Suitable & 0.11 & Safe & 100.28 & Class I & 0.17 & Excellent \\
\hline & P5 & 4.62 & Excellent & 67.90 & Excellent & 14.24 & Excellent & 0.14 & Excellent & 17.64 & Suitable & 0.12 & Safe & 102.14 & Class I & 0.18 & Excellent \\
\hline & P6 & 5.11 & Excellent & 83.50 & Excellent & 14.63 & Excellent & 0.15 & Excellent & 18.25 & Suitable & 0.13 & Safe & 100.76 & Class I & 0.19 & Excellent \\
\hline & P7 & 4.97 & Excellent & 83.50 & Excellent & 14.44 & Excellent & 0.14 & Excellent & 17.81 & Suitable & 0.12 & Safe & 101.91 & Class I & 0.18 & Excellent \\
\hline & P8 & 5.11 & Excellent & 84.70 & Excellent & 13.40 & Excellent & 0.14 & Excellent & 17.47 & Suitable & 0.11 & Safe & 99.94 & Class I & 0.17 & Excellent \\
\hline & P9 & 7.12 & Excellent & 120.40 & Excellent & 16.37 & Excellent & 0.21 & Excellent & 16.96 & Suitable & 0.15 & Safe & 89.58 & Class I & 0.25 & Excellent \\
\hline & P10 & 4.77 & Excellent & 85.00 & Excellent & 15.08 & Excellent & 0.15 & Excellent & 18.72 & Suitable & 0.13 & Safe & 104.25 & Class I & 0.19 & Excellent \\
\hline & Average & 5.25 & Excellent & 85.06 & Excellent & 14.68 & Excellent & 0.15 & Excellent & 18.23 & Suitable & 0.13 & Safe & 99.87 & Class I & 0.19 & Excellent \\
\hline \multirow{11}{*}{ Summer season } & P1 & 2.10 & Excellent & 30.00 & Excellent & 17.67 & Excellent & 0.10 & Excellent & 22.03 & Suitable & 0.13 & Safe & 137.16 & Class I & 0.14 & Excellent \\
\hline & P2 & 2.07 & Excellent & 29.00 & Excellent & 17.51 & Excellent & 0.10 & Excellent & 22.21 & Suitable & 0.13 & Safe & 137.65 & Class I & 0.14 & Excellent \\
\hline & P3 & 2.24 & Excellent & 32.00 & Excellent & 18.70 & Excellent & 0.12 & Excellent & 24.04 & Suitable & 0.15 & Safe & 130.18 & Class I & 0.16 & Excellent \\
\hline & P4 & 2.18 & Excellent & 32.00 & Excellent & 17.08 & Excellent & 0.10 & Excellent & 21.53 & Suitable & 0.13 & Safe & 133.47 & Class I & 0.14 & Excellent \\
\hline & P5 & 2.19 & Excellent & 32.00 & Excellent & 19.71 & Excellent & 0.11 & Excellent & 25.48 & Suitable & 0.14 & Safe & 135.17 & Class I & 0.16 & Excellent \\
\hline & P6 & 2.59 & Excellent & 39.00 & Excellent & 16.33 & Excellent & 0.11 & Excellent & 18.92 & Suitable & 0.12 & Safe & 122.86 & Class I & 0.15 & Excellent \\
\hline & P7 & 2.15 & Excellent & 32.00 & Excellent & 17.80 & Excellent & 0.10 & Excellent & 22.73 & Suitable & 0.13 & Safe & 135.37 & Class I & 0.15 & Excellent \\
\hline & P8 & 2.15 & Excellent & 36.00 & Excellent & 17.40 & Excellent & 0.10 & Excellent & 21.88 & Suitable & 0.13 & Safe & 135.88 & Class I & 0.14 & Excellent \\
\hline & P9 & 5.38 & Excellent & 84.00 & Excellent & 9.51 & Excellent & 0.09 & Excellent & 15.22 & Suitable & 0.07 & Safe & 80.15 & Class I & 0.13 & Excellent \\
\hline & P10 & 2.72 & Excellent & 42.00 & Excellent & 18.16 & Excellent & 0.10 & Excellent & 21.08 & Suitable & 0.12 & Safe & 126.63 & Class I & 0.16 & Excellent \\
\hline & Average & 2.58 & Excellent & 38.80 & Excellent & 16.99 & Excellent & 0.10 & Excellent & 21.51 & Suitable & 0.12 & Safe & 127.45 & Class I & 0.15 & Excellent \\
\hline
\end{tabular}

